УДК 378.046.4:373.58/.5.091.2.011.3-051:51]:004

DOI: 10.37026/2520-6427-2020-104-4-30-36
Світлана ЛИТВИНОВА,

доктор педагогічних наук, стариий науковий співробітник, в.о. заступника директора з наукової роботи Інституту інформаційних технологій $і$ засобів навчання НАПН Украӥни, м. Київ

Майя МАР'СНКО,

кандидат педагогічних наук, старший науковий співробітник відділу хмаро орієнтованих систем інформатизації освіти Інституту інформаційних технологій $і$ засобів навчання НАПН Украӥни, м. Київ

\title{
ПРОГРАМА НАВЧАЛЬНОЇ ДИСЦИПЛІНИ «ХМАРО ОРІЕНТОВАНІ ТЕХНОЛОГІЇ ПІДТРИМКИ НАУКОВО-ОСВІТНЬӦ̈ ДІЯЛЬНОСТІ» ДЛЯ ПІДГОТОВКИ ЗДОБУВАЧІВ ВИЩОЇ ОСВІТИ СТУПЕНЯ «ДОКТОР ФІЛОСОФІї»
}

У статті представлено програму навчальноі дисиипліни «Хмаро орієнтовані технології підтримки науково-освітньої діяльності», спрямовану на підготовку здобувачів вищої освіти ступеня «доктор філософії» (спеціальність 011 «Освітні, педагогічні науки») та засвоєння ними відомостей, відпрацңювання вмінь і навичок, необхідних для застосування хмаро орієнтованих технологій та хмарних сервісів відкритої науки в освіті й наукових дослідженнях. Визначено мету $i$ завдання курсу, подано структуру навчальної дисципліни, зазначено перелік знань, умінь та навичок, яких аспіранти набувають у результаті вивчення матеріалу і виконання практичних робіт.

Укладено навчально-методичну карту дисичиліни «Хмаро орієнтовані технології підтримки науково-освітньої діяльності». Наведено детальний опис тем для практичних занять та самостійної роботи. Виокремлено основні методи навчання (методи організації й здійснення навчально-пізнавальної діяльності та методи стимулювання інтересу до навчання i мотивачії навчально-пізнавальної діяльності) та методи контролю. Представлено розподіл балів, зокрема запропоновано шкалу оцінювання, методичне та інформаційно-методичне забезпечення, а також перелік рекомендованої літератури.

Ключові слова: програма навчальної дисциилліни, хмаро орієнтовані технології, ступінь «доктор фiлософії», науково-освітня діяльність, програма навчальної дисиипліни.

The article presents the working program of the discipline "Cloud oriented technologies to support scientific and educational activities» for applicants for higher education, the degree of "Doctor of Philosophy» (specialty 011 «Educational, pedagogical sciences»). The structure of the program is typical. The hours correspond to the working curriculum. The work program was approved at a meeting of the Academic Council of the Institute of Information Technologies and Learning Tools of the National Academy of Pedagogical Sciences of Ukraine. The description of the discipline, the purpose and objectives of the course are given. The list of knowledge and skills that graduate students acquire as a result of studying the discipline is given. It is indicated what skills and abilities graduate students acquire during the performance of practical work. The program of the academic discipline is described and its structure is given. The educational and methodical map of the discipline "Cloud-oriented technologies of support of scientific and educational activity" is concluded. A detailed description of the topics of practical classes and independent work is given. Among the teaching methods are: methods of organization and implementation of educational and cognitive activities and methods of stimulating interest in learning and motivation of educational and cognitive activities. The main methods of control are also established: oral and self-control. The distribution of points received by graduate students is determined and the evaluation scale is presented. Available methodological support, information and methodological support and recommended literature. The discipline is studied in the 2nd year of study in the IV semester at the educational and scientific level "Doctor of Philosophy». The number of training weeks is 2. The discipline is included in the cycle of professional training (normative disciplines of the cycle of professional training). Aimed at the acquisition of information and development of skills necessary for the application of cloud-based technologies and cloud services of open science in education and research. 
Key words: educational curriculum, cloud-oriented technologies, degree "Doctor of Philosophy», scientific and educational activities, curriculum.

Постановка проблеми. Координаційною радою 3 розвитку цифрової економіки та суспільства цифровізацію (з англ. Digitalization - упровадження сучасних иифрових технологій в різні сфери життя та виробництва) визначено найважливішим фактором економічного зростання української економіки, сучасним трендом розвитку та новою реальністю України. Зважаючи на це, підготовка фахівців із питань цифровізації освітньої галузі стає однією з пріоритетних. Підготовку таких фахівців здійснюють у закладах вищої освіти. Однак у Законі України «Про вищу освіту» зазначається, що наукові установи також можуть здійснювати підготовку докторів філософіï за власною освітньо-науковою програмою згідно 3 отриманою ліцензією на відповідну освітню діяльність або за освітньо-науковою програмою [1].

Ураховуючи зазначене вище, Вченою радою Інституту інформаційних технологій і засобів навчання НАПН України було схвалено (протокол № 9 від 11.07.2019р.) навчальний план для денної та заочної форм навчання третього рівня вищої освіти (освітньо-науковий) для ступеня вищої освіти «доктор філософії» (перший науковий). Відповідно до цього до плану освітнього процесу (цикл професійної підготовки) включено навчальну дисципліну «Хмаро орієнтовані технології підтримки науковоосвітньої діяльності». У зв'язку з цим постало завдання розробити та укласти програму означеної дисципліни, що передбачена планом навчального процесу для галузі знань 01 «Освіта. Педагогіка» (спеціальність 011 «Освітні, педагогічні науки», спеціалізація «Інформаційно-комунікаційні технології в освіті», термін навчання - 4 роки (30 кредитів)).

Аналіз наукових досліджень і публікацій. У процесі аналізу наукових публікацій було з'ясовано, що в окремих закладах вищої освіти (далі-3BO) Положення про програму навчальної дисципліни [4], в яких окреслено приблизний зміст розділів та структуру програми, наводиться порядок оформлення та затвер- дження даного документу. Так, у Національній академії наук затверджено Методичні рекомендації стосовно розроблення та оформлення програми навчальної дисципліни [3], в яких описано загальні положення, наведено зразок програми, форми документів щодо актуалізації програм та їхня орієнтована структура.

У Листі МОН України від 09.07.2018 p. № 1/9-434 «Щодо рекомендацій із навчально-методичного забезпечення» (додаток 2) подано рекомендації до структури та змісту програми навчальної дисципліни, зокрема наведено основні призначення програми, iї складники та рекомендовану структуру. Авторська програма навчальної дисципліни «Хмаро орієнтовані технології підтримки науково-освітньої діяльності» укладена саме з урахуванням означених рекомендацій [2]. Оскільки всі інші положення та методичні рекомендації розроблені для конкретного ЗВО спираються саме на Лист МОН України від 09.07.2018 р. № 1/9-434, то автори взяли за основу саме таку структуру.

Метою статті $є$ укладення програми навчальної дисципліни «Хмаро орієнтовані технології підтримки науково-освітньої діяльності», спрямовану на підготовку здобувачів вищої освіти ступеня «доктор філософії» (спеціальність 011 «Освітні, педагогічні науки»).

Виклад основного матеріалу дослідження. Підготовка фахівців із питання цифровізації освіти здійснюється в галузі знань «Освіта. Педагогіка» на спеціальності 011 «Освітні, педагогічні науки», зокрема 13.00.10 - інформаційно-комунікаційні технології в освіті.

Програма навчальної дисципліни «Хмаро орієнтовані технології підтримки науково-освітньої діяльності» була укладена 3 урахуванням сучасних педагогічних методик та останніх доробок із напрямів: використання хмарних сервісів та хмаро орієнтованих систем; упровадження принципів відкритої науки в освітній процес; використання доповненої та віртуальної реальності в освітньому процесі та науково-освітній діяльності. При цьому були враховані рівні сформованості умінь та навичок майбутніх докторів філософії, набутих у межах дисциплін циклу загальної підготовки.

\section{1. Опис навчальної дисципліни}

\begin{tabular}{|c|c|c|c|}
\hline \multirow{2}{*}{ Найменування показників } & \multirow{2}{*}{$\begin{array}{l}\text { Галузь знань, напрям підготовки, } \\
\text { освітньо-кваліфікаційний рівень }\end{array}$} & \multicolumn{2}{|c|}{$\begin{array}{c}\text { Характеристика навчальної } \\
\text { дисципліни }\end{array}$} \\
\hline & & $\begin{array}{c}\text { денна форма } \\
\text { навчання }\end{array}$ & $\begin{array}{c}\text { заочна форма } \\
\text { навчання }\end{array}$ \\
\hline \multirow[b]{2}{*}{ Кількість кредитів - 2} & Галузь знань & \multirow{2}{*}{\multicolumn{2}{|c|}{ Нормативна }} \\
\hline & $\begin{array}{c}\text { Спеціальності: } \\
011 \text { «Освітні, педагогічні науки» }\end{array}$ & & \\
\hline \multirow{2}{*}{$\begin{array}{l}\text { Модулів }-1 \\
\text { Змістових модулів -2 }\end{array}$} & \multirow{12}{*}{$\begin{array}{l}\text { Освітній рівень: } \\
\text { (PhD-рівень) }\end{array}$} & \\
\hline & & \multicolumn{2}{|c|}{\begin{tabular}{l|l} 
Р1К ПАДГТТовКИ \\
$2-и ̆$
\end{tabular}} \\
\hline \multirow{2}{*}{$\begin{array}{l}\text { Змістових модулів - } 2 \\
\text { Загальна кількість годин - } 60\end{array}$} & & \multicolumn{2}{|c|}{ Семестр } \\
\hline & & 4-й & 4-й \\
\hline \multirow{8}{*}{$\begin{array}{l}\text { Тижневих годин для денної } \\
\text { форми навчання: } \\
\text { аудиторних - } 2 \text { год., } \\
\text { самостійної роботи студента - } \\
\mathbf{3 0} \text { год. }\end{array}$} & & \multicolumn{2}{|c|}{ Лекції } \\
\hline & & 4 год. & 4 год. \\
\hline & & \multicolumn{2}{|c|}{ Практичні/семінарські } \\
\hline & & 6 год. & 6 год. \\
\hline & & \multicolumn{2}{|c|}{ Самостійна робота } \\
\hline & & 50 год. & 50 год. \\
\hline & & \multicolumn{2}{|c|}{ Вид контролю: } \\
\hline & & \multicolumn{2}{|c|}{ залік } \\
\hline
\end{tabular}




\section{2. Мета та завдання навчальної дисципліни}

Мета курсу «Хмаро орієнтовані технології підтримки науково-освітньої діяльності» полягає у формуванні в аспірантів вміння використовувати хмаро орієнтовані технології, зокрема цифрові інструменти хмари відкритої науки та програмні продукти у сучасних наукових дослідженнях та освітній діяльності.

Мета досягається шляхом теоретичного опанування основ інформатизації освітньої та наукової галузей, тенденцій розвитку хмаро орієнтованих технологій у XXI ст., практичного оволодіння аспірантами навичок роботи із хмаро орієнтованими сервісами, цифровими інструментами хмари відкритої науки, побудови відповідних інформаційних моделей, узагальнення й опрацювання результатів дослідження.

Завдання курсу:

- опанування аспірантами теоретичних основ розвитку хмаро орієнтованих технологій;

- усвідомлення необхідності використання інформаційно-комунікаційних технологій в освіті та наукових дослідженнях;

- формування знань про форми, методи та підходи щодо використання хмаро орієнтованих технологій для підтримки освітньої та наукової діяльності;

- отримання практичних навичок використання хмаро орієнтованих технологій, зокрема сервісів хмари відкритої науки.

Вивчення курсу дозволить здобувачам освіти використовувати в освітній діяльності та наукових дослідженнях сучасні технології, зорієнтує на впровадження новітніх підходів до організації освітнього процесу, реалізацію спільних проєктів, проведення онлайн-конференцій, вебінарів, цифрових вебквестів, дистанційного навчання, опрацювання різноманітних даних.

У результаті вивчення навчальної дисципліни аспірант повинен

Знати:

- основні поняття та характеристики хмаро орієнтованого середовища;

- генезу формування хмаро орієнтованого освітнього середовища;

- концепції використання хмаро орієнтованих технологій,

- вітчизняний і зарубіжний досвід використання хмаро орієнтованих технологій;

- основні складники хмаро орієнтованого середовища;

- моделі хмаро орієнтованих середовищ;

- особливості добору хмаро орієнтованих технологій;

- теоретичні основи впровадження інформаційних технологій в освітньо- наукову діяльність;

- основи кібербезпеки в мережі Інтернет;

- умови здійснення інтерактивної комунікації;

- вимоги до організації роботи над цифровими вебквестами;

- організацію та здійснення співпраці в хмаро орієнтованому середовищі;

- функціональні можливості та особливості використання сервісів хмари відкритої науки;

- основні підходи до використання цифрових сервісів для підтримування освітньо-наукової діяльності;

- основні засади використання віртуального класу.

Уміти:

- орієнтуватися в цифровому просторі;
- здійснювати пошук наукових даних та даних за спеціальністю;

- добирати хмаро орієнтовані технології для підтримування освітньої діяльності та наукових досліджень;

- ефективно використовувати хмарні сервіси на практиці;

- використовувати хмаро орієнтовані середовища для організації дистанційної форми навчання;

- редагувати, коригувати та створювати цифрові об'єкти для забезпечення освітньо-наукової діяльності;

- здійснювати інтерактивну освітньо-наукову комунікацію;

- організовувати цифрові освітні вебквести;

- розробляти моделі хмаро орієнтованих середовищ;

- співпрацювати у хмаро орієнтованому середовищі;

- використовувати у своїй роботі віртуальний клас.

Підвищенню ефективності навчальних занять сприятиме передбачене програмою виконання практичних робіт, завдяки чому аспіранти набувають таких умінь та навичок:

1. Працювати 3 хмарними сервісами.

2. Знаходити в мережі Інтернет необхідну для використання в науково-дослідному процесі інформацію.

3. Вирішувати завдання, пов'язані з опрацюванням інформації з використанням хмарних сервісів (створення текстових документів, таблиць, презентацій, публікацій тощо).

4. Самостійно створювати інформаційні матеріали для використання в науково-дослідному процесі.

5. Досліджувати розвиток хмаро орієнтованих систем.

6. Опрацьовувати наукову літературу щодо використання хмарних технологій, хмаро орієнтованих систем та хмарних сервісів.

7. Аналізувати і підбирати той чи інший хмарний сервіс для використання в наукових дослідженнях.

8. Опрацьовувати відкриті джерела 3 метою ознайомлення 3 технологією використання хмарних ресурсів.

9. Аналізувати ефективність використання хмарних сервісів у науково-дослідному процесі.

10. Здійснювати обробку експериментальних результатів дослідження з використанням хмарних сервісів.

11. Працювати з хмарними сервісами аналізу даних.

\section{3. Програма навчальної дисципліни Змістовий модуль 1.}

Використання хмаро оріснтованих технологій у наукових дослідженнях

Тема 1. Формування і розвиток хмаро оріснтованого середовища підтримки науково-освітньої діяльності.

Інформатизація освітнього процесу як чинник iii розвитку в XXI ст. Освітнє середовище. Цифрове освітнє середовище. Віртуальний клас. Основні поняття та характеристики хмаро орієнтованого середовища. Хмаро орієнтовані технології для підтримування науково-освітньої діяльності. Технології віртуальної та доповненої реальності. 
Тема 2. Міжнародні освітні проєкти в Україні. Широкомасштабне впровадження хмаро оріснтованих технологій.

Етапи широкомасштабного впровадження цифрових технологій. Генеза формування хмаро орієнтованого середовища. Вітчизняний і зарубіжний досвід упровадження хмаро орієнтованих технологій. Освітні ініціативи Інтел Програма «Навчання для майбутнього», «Хмарні сервіси в освіті» в Україні. Широкомасштабне впровадження дистанційних форм науково-освітньої діяльності: уроки пандемії COVID-19.

Тема 3. Хмаро оріснтовані технології в науково-освітній діяльності.

Особливості використання хмарних сервісів Google, Microsoft, хмари відкритої науки EOSC у наукових дослідженнях і освітній діяльності. Методика використання віртуального класу. Методика проведення вебконференцій за допомогою сервісів Zoom, Skype, Teams. Використання цифрових вебквестів. Особливості організації дистанційної форми навчання в контексті науково-освітньої діяльності. Використання хмарних сервісів відкритої науки.

Тема 4. Просктування інформаційно-освітнього середовища науково-освітньої діяльності

Проєктування, його етапи та форми. Проєктування інформаційно-освітнього середовища. Призначення сайту в науково-освітній діяльності. Використання мережних і соціальних сервісів, вебтехнологій, сервісів збору та оброблення даних для розвитку інформаційно-освітнього середовища науково-освітньої діяльності (хмарних сервісів відкритої науки, сервісів доповненої та віртуальної реальності).

\section{Структура навчальної дисципліни}

\begin{tabular}{|c|c|c|c|c|c|c|}
\hline \multirow[b]{3}{*}{$\begin{array}{l}\text { Назви змістових } \\
\text { модулів і тем }\end{array}$} & \multicolumn{6}{|c|}{ Кількість годин } \\
\hline & \multirow[b]{2}{*}{$\begin{array}{l}0 \\
\vdots \\
0 \\
0 \\
D\end{array}$} & \multicolumn{5}{|c|}{ зокрема } \\
\hline & & 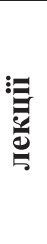 & 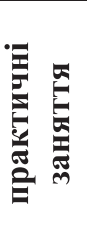 & 离 & 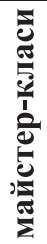 & 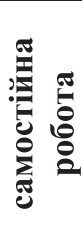 \\
\hline 1 & 2 & 3 & 4 & 5 & 6 & 7 \\
\hline \multicolumn{7}{|c|}{ Модуль } \\
\hline \multicolumn{7}{|c|}{ Змістовий модуль 1. Використання хмаро оріснтованих технологій у наукових дослідженнях } \\
\hline $\begin{array}{l}\text { Tема 1. Формування і розвиток хмаро орієнтованого середовища підтримки } \\
\text { науково-освітньої діяльності }\end{array}$ & 13 & 1 & 2 & & & 10 \\
\hline $\begin{array}{l}\text { Tема 2. Міжнародні освітні проєкти в Україні. Широкомасштабне впрова- } \\
\text { дження хмаро орієнтованих технологій }\end{array}$ & 13 & 1 & 2 & & & 10 \\
\hline Тема 3. Хмаро орієнтовані технології в науково-освітній діяльності & 13 & 1 & 2 & & & 10 \\
\hline $\begin{array}{l}\text { Тема 4. Проєктування інформаційно-освітнього середовища науково-освіт- } \\
\text { ньої діяльності }\end{array}$ & 21 & 1 & & & & 20 \\
\hline Усього & 60 & 4 & 6 & & & 50 \\
\hline
\end{tabular}

\section{4. Навчально-методична карта дисципліни}

«Хмаро оріснтовані технології підтримки науково-освітньої діяльності

Разом: 10 год., зокрема лекції - 4 год., практичні заняття - 6 год.

\begin{tabular}{|c|c|c|c|c|}
\hline Тиждень & I & II & III & IV \\
\hline Модулі & \multicolumn{4}{|c|}{ Змістовий модуль } \\
\hline Назва модуля & \multicolumn{4}{|c|}{ Використання хмаро орієнтованих технологій у наукових дослідженнях } \\
\hline Бали за модуль & \multicolumn{4}{|c|}{100} \\
\hline Заняття & 1 & 2 & 3 & 4 \\
\hline \multicolumn{5}{|l|}{ Дати } \\
\hline $\begin{array}{c}\text { Теми } \\
\text { лекцій }\end{array}$ & $\begin{array}{c}\text { Формування і розвиток } \\
\text { хмаро орієнтованого } \\
\text { середовища підтримки } \\
\text { науково-освітньої } \\
\text { діяльності }\end{array}$ & \begin{tabular}{|} 
Міжнародні освітні \\
проєкти в Україні. \\
Широкомасштабне \\
впровадження хмаро \\
орієнтованих \\
технологій
\end{tabular} & $\begin{array}{c}\text { Хмаро } \\
\text { орієнтовані } \\
\text { технології в } \\
\text { науково-освітній } \\
\text { діяльності }\end{array}$ & $\begin{array}{c}\text { Проєктування } \\
\text { інформаційно- } \\
\text { освітнього середовища } \\
\text { науково-освітньої } \\
\text { діяльності }\end{array}$ \\
\hline $\begin{array}{c}\text { Теми } \\
\text { практичних } \\
\text { занять }\end{array}$ & $\begin{array}{c}\text { Формування і розвиток } \\
\text { хмаро орієнтованого } \\
\text { середовища підтримки } \\
\text { науково-освітньої } \\
\text { діяльності } \\
\end{array}$ & \begin{tabular}{|c|} 
Широкомасштабне \\
впровадження хмаро \\
орієнтованих \\
технологій
\end{tabular} & $\begin{array}{c}\text { Хмаро } \\
\text { орієнтовані } \\
\text { технології в } \\
\text { науково-освітній } \\
\text { діяльності } \\
\end{array}$ & $\begin{array}{c}\text { Проєктування } \\
\text { інформаційно- } \\
\text { освітнього середовища } \\
\text { науково-освітньої } \\
\text { діяльності } \\
\end{array}$ \\
\hline Бали & 12 & 12 & 12 & 12 \\
\hline $\begin{array}{c}\text { Самостійна } \\
\text { робота (ІНДЗ) }\end{array}$ & \multicolumn{4}{|c|}{506} \\
\hline
\end{tabular}




\section{5. Теми практичних занять}

\begin{tabular}{|c|l|c|}
\hline $\begin{array}{c}\text { № } \\
\text { 3/п }\end{array}$ & \multicolumn{1}{|c|}{ Назва теми } & $\begin{array}{c}\text { Кількість } \\
\text { годин }\end{array}$ \\
\hline 1 & $\begin{array}{l}\text { Формування і розвиток хмаро орієнтованого середовища підтримки науково-освітньої } \\
\text { діяльності. Робота з хмарними сервісами Goоgle }\end{array}$ & 2 \\
\hline 2 & Широкомасштабне впровадження хмаро орієнтованих технологій. Poбота з Google Kласом & 2 \\
\hline 3 & Хмаро орієнтовані технології в науково-освітній діяльності. Pобота з Zoоm, Skype, Teams & 2 \\
\hline
\end{tabular}

\section{6. Самостійна робота}

\begin{tabular}{|c|l|c|}
\hline $\begin{array}{c}\text { № } \\
\text { 3/п }\end{array}$ & \multicolumn{1}{|c|}{ Назва теми } & $\begin{array}{c}\text { Кількість } \\
\text { годин }\end{array}$ \\
\hline 1 & $\begin{array}{l}\text { Формування і розвиток хмаро орієнтованого середовища підтримки науково-освітньої } \\
\text { діяльності. Створення сайту інструментами Goоgle }\end{array}$ & 30 \\
\hline 2 & $\begin{array}{l}\text { Широкомасштабне впровадження хмаро оріснтованих технологій. Розгортання та } \\
\text { наповнення Gоogle Класу }\end{array}$ & 10 \\
\hline 3 & $\begin{array}{l}\text { Хмаро орієнтовані технології в науково-освітній діяльності. Створення та проведення } \\
\text { зустрічі в Zоот, Skуре, Tеатs }\end{array}$ & 10 \\
\hline \multicolumn{2}{|l}{ Усього } & $\mathbf{5 0}$ \\
\hline
\end{tabular}

\section{7. Методи навчання}

I. Методи організації та здійснення навчально-пізнавальної діяльності

1. За джерелом інформації:

- Словесні: лекція (традиційна, проблемна) із застосуванням хмарних сервісів та систем, пояснення, розповідь, бесіда.

- Наочні: спостереження, ілюстрація, демонстрація.

- Практичні: вправи.

2. За логікою передачі та сприймання навчальної інформації: індуктивні, дедуктивні, аналітичні, синтетичні.

3. За ступенем самостійності мислення: репродуктивні, пошукові, дослідницькі.
4. За ступенем керування навчальною діяльністю: під керівництвом викладача; виконання практичних завдань.

II. Методи стимулювання інтересу до навчання і мотивацї̈ навчально-пізнавальної діяльності:

1. Методи стимулювання інтересу до навчання: навчальні дискусії; створення ситуації пізнавальної новизни; створення ситуацій зацікавленості (метод цікавих аналогій тощо).

\section{8. Методи контролю}

Методи усного контролю: індивідуальне опитування, фронтальне опитування, співбесіда.

Методи самоконтролю: вміння самостійно оцінювати свої знання, самоаналіз.

9. Розподіл балів, які отримують аспіранти

\begin{tabular}{|c|c|c|c|c|}
\hline \multicolumn{4}{|c|}{ Поточне тестування та самостійна робота } & Сума \\
\hline \multicolumn{4}{|c|}{ Змістовий модуль } & \multirow{3}{*}{100} \\
\hline T1 & $\mathrm{T} 2$ & T3 & T4 & \\
\hline \multicolumn{4}{|c|}{98 б. } & \\
\hline
\end{tabular}

Шкала оцінювання (національна та СКТС)

\begin{tabular}{|c|c|c|}
\hline $\begin{array}{c}\text { Рейтингова } \\
\text { оцінка }\end{array}$ & $\begin{array}{l}\text { Сума балів за всі види } \\
\text { навчальної діяльності }\end{array}$ & \multicolumn{1}{|c|}{ Значення оцінки } \\
\hline $\mathbf{A}$ & $90-100$ & $\begin{array}{l}\text { Відмінно - відмінний рівень знань (умінь) у межах обов’язкового } \\
\text { матеріалу з можливими незначними недоліками }\end{array}$ \\
\hline $\mathbf{B}$ & $82-89$ & $\begin{array}{l}\text { Дуже добре - достатньо високий рівень знань (умінь) у межах обов’яз- } \\
\text { кового матеріалу без суттвих (грубих) помилок }\end{array}$ \\
\hline $\mathbf{C}$ & $75-81$ & $\begin{array}{l}\text { Добре - загалом добрий рівень знань (умінь) із незначною кількістю } \\
\text { помилок }\end{array}$ \\
\hline $\mathbf{D}$ & $69-74$ & $\begin{array}{l}\text { Задовільно - посередній рівень знань (умінь) зі значною кількістю недо- } \\
\text { ліків, достатній для подальшого навчання або професійної діяльності }\end{array}$ \\
\hline $\mathbf{E}$ & $60-68$ & Достатньо- мінімально можливий допустимий рівень знань (умінь) \\
\hline $\mathbf{F X}$ & $35-59$ & $\begin{array}{l}\text { Незадовільно з можливістю повторного складання - незадовільний } \\
\text { рівень знань із можливістю повторного перескладання за умови належ- } \\
\text { ного самостійного доопрацювання }\end{array}$ \\
\hline $\mathbf{F}$ & $\begin{array}{l}\text { Незадовільно з обов'язковим повторним вивченням курсу - досить низь- } \\
\text { кий рівень знань (умінь), що вимагає повторного вивчення дисципліни }\end{array}$ \\
\hline
\end{tabular}

\section{0. Методичне забезпечення}

Методичне забезпечення дисципліни передбачає наявність:

- опорних конспектів лекцій;
- методичних посібників;

- навчальних посібників;

- цифрових ресурсів;

- власне навчальної програми. 


\section{1. Рекомендована література Базова}

1. Биков В. Ю., Гуржій А. М., Шишкіна М. П. Концептуальні засади формування і розвитку хмаро орієнтованого навчально-наукового середовища закладу вищої педагогічної освіти. Сучасні інформаиійні технології та інновачійні методики навчання в підготовиі фахівиів: методологія, теорія, досвід, проблеми. 2018. № 50. С. 20-25.

2. Вакалюк Т. А. Хмарні технології в освіті: навчально-методичний посібник для студентів фізико-математичного факультету. Житомир : Вид-во ЖДУ, 2016. 72 с.

3. Коротун О. В. Використання хмаро орієнтованого середовища у навчанні баз даних майбутніх учителів інформатики : дис. ... канд. пед. наук : 13.00.10 / Житомирський державний університет імені Івана Франка, Інститут інформаційних технологій і засобів навчання НАПН України. Київ, 2018. 356 с.

4. Коротун О. В. Хмаро орієнтована система управління навчанням Canvas. Педагогічні науки: теорія, історія, інновачійні технології. 2016. № 55 (1). С. 230-239.

5. Литвинова С. Г. Віртуальні предметні спільноти. Інформаційно-комунікаційні технології в освіmi: досвід, інновачї, технічне забезпечення : збірник матеріалів Всеукраїнської науково-практичної конференції (м. Суми, 1-2 березня 2012 року). Суми : СОІППО, 2012.

6. Литвинова С. Г. Основні етапи і компоненти проектування хмаро орієнтованого навчального середовища загальноосвітнього навчального закладу. Педагогіка вищої школи: методологія, теорія, технології. Вища освіта Украӥни : теоретичний та науково-методичний часопис: у 3 т. 2014. Вип. 3 (541). Т. 2.

7. Литвинова С. Г. Поняття та основні характеристики хмаро орієнтованого навчального середовища середньої школи. Інформаиіийні технології $i$ засоби навчання: електронне наукове фахове видання. 2014. № 2 (40). C. 26-41. URL: http://journal.iitta.gov.ua/ index.php/itlt/article/view/970/756\#.U2aW6IF vzA.

8. Литвинова С. Г. Хмарні технології: особливості діяльності вчителів-предметників у віртуальних предметних спільнотах. Теорія та методика електронного навчання. Кривий Ріг : Видавничий відділ КМI. Вип. IV. 2013.

9. Литвинова С. Г., Спірін О. М., Анікіна Л. П. Хмарні сервіси Office 365 : навч. посібник / за заг. ред. С. Г. Литвинової. Київ : Компринт, 2015. 170 с.

10. Литвинова С. Г. Проектування хмаро орієнтованого навчального середовища загальноосвітнього навчального закладу : монографія. Київ : Компринт, 2016.354 c.

11. Литвинова С. Г. Методика проектування хмаро орієнтованого навчального середовища загальноосвітнього навчального закладу на рівні керівника. Комп 'ютер у школі та сім'ї. 2015. № 2 (122). С. 5-11.

12. Литвинова С. Г. Методика проектування хмаро орієнтованого навчального середовища загальноосвітнього навчального закладу на рівні вчителя-предметника. Наукові записки. Серія «Проблеми методики фізико-математичної та технологічної освіти» / за. заг. ред. М. І. Садового та О. В. Сжової. Кіровоград : РВВ КДПУ ім. В. Винниченка, 2015. Вип. 7. Ч. 1.

13. Литвинова С. Г. Методика проектування та використання хмаро орієнтованого навчального середовища загальноосвітнього навчального закладу : методичні рекомендації. Київ : Компринт, 2015. 280 с.

14. Литвинова С. Г. Теоретико-методичні основи проектування хмаро орієнтованого навчального середовища загальноосвітнього навчального закладу: дис. ... д-ра пед. наук : 13.00.10 / Інститут інформаційних технологій і засобів навчання НАПН України. Київ, 2016. 602 с.

15. Литвинова С. Г. Напрями цифрової трансформації освітнього процесу закладів загальної середньої освіти України. Сучасні тенденції розвитку інформаційно-комунікаційних технологій в освіті: зб. матеріалів II Міжнародної науково-практичної конференції в рамках Міжнародного освітнього форуму «Цифрова трансформація освіти» / упоряд. Н. А. Басараба ; за ред. А. Л. Черній, І. В. Вєтрова, В. С. Безрученка. Рівне : РОІППО, 2020. С. 33-35.

16. Литвинова С. Г. Цифрові інструменти віртуального освітнього простору сучасного викладача. Засоби і технологї сучасного навчального середовища : матеріали XVI (XXVI) Міжнародної науково-практичної конференції (м. Кропивницький, травень 2020 р. Кропивницький : Ексклюзив-Систем, 2020. C. $21-22$.

17. Литвинова С. Г. Чотири підходи до організації дистанційної форми навчання в закладах освіти. Актуальні проблеми в системі освіти: заклад загальної середньої освіти - доуніверситетська підготовка - заклад вищої освіти : зб. наук. праць VI Всеукраїнської науково-практичної конференції (м. Київ, 9 червня 2020 р.) / за наук. ред. Н. П. Муранової ; Національний авіаційний університет. Київ : HAУ, 2020. С. 92-96.

18. Литвинова С. Г. Хмаро орієнтовані сервіси як складники віртуального наукового офісу. Наукова школа академіка Івана Зязюна у праиях його соратників та учнів : матеріали VI науково-практичної конференції (м. Харків, 28 травня 2020 р). Харків, 2020. C. 290-293.

19. Теоретико-методологічні засади інформатизації освіти та практична реалізація інформаційно-комунікаційних технологій в освітній сфері України : монографія / за наук. ред. В. Ю. Бикова, С. Г. Литвинової, В. І. Лугового. Київ : ЦП Компринт, 2019. 214 c.

20. Литвинова С. Г. Теоретико-методологічні основи моделювання і використання хмаро орієнтованого середовища для навчання учнів закладу загальної середньої освіти : монографія. Київ : ЦП Компринт, 2019. 240 с.

21. Носенко Ю. Г., Попель М. В., Шишкіна М. П. Хмарні сервіси і технології у науковій і педагогічній діяльності : методичні рекомендації. Київ : ІІТЗН НАПН України, 2016. 73 с.

\section{Допоміжна}

1. Биков В. Ю. Інноваційний розвиток засобів і технологій систем відкритої освіти. Сучасні інформаиійні технології та інноваційні методики у підготовизі фахівиів: методологія, теорія, досвід, проблеми : зб. наук. праць. 2012. Вип. 29. С. 32-40.

2. Биков В. Ю. Теоретико-методологічні засади створення і розвитку сучасних засобів та е-технологій навчання. Розвиток педагогічної $і$ психологічної наук в Україні 1992-2002 : зб. наук. праць до 10-річчя АПН України. 2002. Ч. 2. С. 182-199.

3. Биков В. Ю. Моделі організаційних систем відкритої освіти : монографія. Київ : Атіка, 2008. 
4. Биков В. Ю., Кремень В. Г. Категорії простір і середовище: особливості модельного подання та освітнього застосування. Теорія і практика управління соиіальними системами: філософія, психологія, педагогіка, соиіологія. 2013. № 3. С. 3-16.

5. Биков В. Ю. Теоретико-методологічні засади моделювання навчального середовища педагогічних систем відкритої освіти. Наукові записки. Серія «Педагогічні науки». 2008. Вип. 77. Ч. 1. С. 3-12.

6. Мар'єнко М. В. Наукові платформи та хмарні сервіси, їх місце у системі наукової освіти вчителя. Фізико-математична освіта. 2019. № 4 (22). C. $12-18$

7. Попель М. В. Організація навчання математичних дисциплін у SageMathCloud : навчальний посібник. Вид. 2-ге, виправл. Кривий Ріг : Видавничий відділ ДВНЗ «Криворізький національний університет», 2016. $111 \mathrm{c}$.

8. Попель М. В. Хмарний сервіс CoCalc як засіб формування професійних компетентностей учителя математики : монографія. Кривий Ріг : Видавничий центр Криворізького національного університету, 2018. $241 \mathrm{c}$.

9. Шишкіна М. П. Формування і розвиток хмаро орієнтованого освітньо-наукового середовища вищого навчального закладу : монографія. Київ : УкрIHTEI, 2015. 256 с.

10. Шишкіна М. П. Теоретико-методичні засади формування і розвитку хмаро орієнтованого освітньо-наукового середовища вищого навчального закладу : дис. ... д-ра пед. наук : 13.00.10 / Інститут інформаційних технологій і засобів навчання НАПН України. Київ, 2016. 441 с.

11. Шишкіна М. П., Попель М. В. Використання хмаро орієнтованих сервісів опрацювання даних у системах відкритої науки. Інформаційні технологї̈ 6 освіті. 2019. № 2 (39). С. 7-19.

12. Шишкіна М. П., Попель М. В. Формування хмаро орієнтованого середовища навчання математичних дисциплін на базі SageMathCloud. Інформаиійні технології в освіті. 2016. № 1 (26). С. 148-165.

1. https://www.office.com

\section{Інформаційні ресурси} help

2. http://office.microsoft.com/uk-ua/powerpoint-

3. http://virt-ikt.blogspot.com/

4. https://www.facebook.com/slytvynova

5. https://www.facebook.com/groups/1429370987 315738

6. https://www.google.com.ua/

7. https://classroom.google.com

8. https://www.skype.com/ru/

9. https://www.microsoft.com/uk-ua/microsoft-365/ microsoft-teams/free

10. https://zoom.us/

\section{2. Інформаційно-методичне забезпечення}

Інформаційно-методичне забезпечення викладання навчальної дисципліни передбачає наявність сучасних технічних засобів навчання, як-от: мультимедійний комп'ютер, мультимедійний проектор, інтерактивна дошка SMART Board, хмаро орієнтовані системи та сервіси.

У ході занять та самостійної роботи студентів використовуються методичні рекомендації щодо вивчення дисципліни, ілюстративні комп’ютерні дидактичні матеріали, розроблені викладачами.

Серед інформаційних ресурсів при вивченні дисципліни варто виокремити: електронну бібліотеку
НАПН України; джерела мережі Інтернет, інформаційно-методичні матеріали викладачів та ін.

Таким чином, дисципліна «Хмаро орієнтовані технології підтримки науково-освітньої діяльності» належить до переліку дисциплін вільного вибору аспіранта. Вона спрямована на засвоєння відомостей та відпрацювання вмінь і навичок, необхідних для застосування хмарних сервісів та хмарних сервісів відкритої науки, хмаро орієнтованих систем в освіті та наукових дослідженнях. Програма дисципліни розкриває особливості використання хмарних сервісів навчання, управління і підтримки наукових досліджень, зокрема надаються практичні рекомендації щодо використання хмарних сервісів та хмаро орієнтованих систем для проведення дисертаційного дослідження і представлення наукових результатів (оприлюднення та апробація).

Висновки. Зважаючи на викладене вище, зазначимо, що навчальна дисципліна «Хмаро орієнтовані технології підтримки науково-освітньої діяльності» посідає одне 3 ключових місць у циклі професійної підготовки докторів філософії Інституту інформаційних технологій і засобів навчання НАПН України, оскільки сприяє формуванню не лише грунтовного теоретичного базису, а й у цілому формує практичні навички роботи з хмарними сервісами та хмаро орієнтованими системами. Крім того, прослідковується тісний зв'язок із науково-освітньою діяльністю майбутніх докторів філософії, оскільки у процесі вивчення дисципліни здобувачі вищої освіти можуть на власному досвіді переконатися в ефективності використання хмаро орієнтованих технологій не лише в освітньому процесі, а й під час проведення педагогічного експерименту, підготовки наукових статей, написання дисертації та іншої наукової продукції. Отже, навчальна дисципліна $є$ актуальною та необхідною складовою підготовки докторів філософії в галузі освіти.

Перспективи подалыших розвідок у даному напрямі вбачаємо в розробці навчально-методичного комплексу для підтримки викладання навчальної дисципліни «Хмаро орієнтовані технології підтримки науково-освітньої діяльності».

\section{СПИСОК ВИКОРИСТАНОЇ ЛІТЕРАТУРИ}

1. Закон України «Про вищу освіту». URL: https:// zakon.rada.gov.ua/laws/show/1556-18\#Text (дата звернення: 15.10.2020).

2. Лист МОН України від 09.07.2018 р. № 1/9-434 «Щодо рекомендацій із навчально-методичного забезпечення». URL: https://mon.gov.ua/ua/npa/listmon-19-434-vid-09072018-roku-shodo-rekomendacijz-navchalno-metodichnogo-zabezpechennуа (дата звернення: 15.10.2020).

3. Методичні рекомендації до розроблення та оформлення робочої програми навчальної дисципліни. URL: https://nau.edu.ua/wp-content/ uploads/2020/05/metod-rekomendacziyi-novi.pdf (дата звернення: 15.10.2020).

4. Положення про робочу програму навчальної дисципліни. URL: https://rshu.edu.ua/images/nmr/ pol rob prog navch disc 2019.pdf (дата звернення: $15 . \overline{10} .2020)$

Дата надходження до редакиії: 16.10.2020 p. 